\title{
Morphometrics, life history and population biology of the Ponto-Caucasian slave-making ant Myrmoxenus tamarae (Hymenoptera: Formicidae)
}

\author{
NAna GRATIASHVILI ${ }^{1,2}$, Masaki SUEFUJI ${ }^{1}$, Shalva BARJADZE ${ }^{3}$ and JÜRgEn HEINZE ${ }^{1}$ \\ ${ }^{1}$ Biologie I, Universität Regensburg, 93040 Regensburg, Germany; e-mails: nanagratiashvili@yahoo.com; \\ Masaki.Suefuji@biologie.uni-regensburg.de; Juergen.Heinze@biologie.uni-regensburg.de \\ ${ }^{2}$ Institute of Zoology, Ilia State University, Giorgi Tsereteli 3, 0162 Tbilisi, Georgia \\ ${ }^{3}$ Institute of Entomology, Agricultural University of Georgia, 13 $3^{\text {th }} \mathrm{km}$ of David Aghmashenebeli Alley, 0159 Tbilisi, Georgia; \\ e-mail: shalva.barjadze@yahoo.com
}

Key words. Hymenoptera, Formicidae, Myrmoxenus, slave-making ants, morphometrics, colony structure, population biology

\begin{abstract}
The ant genus Myrmoxenus consists of about ten socially parasitic species including active slave-makers and workerless "degenerate slave-makers". Myrmoxenus tamarae was previously known only from type material, two workers collected at Daba, Georgia and nothing was known about its life history, colony structure or the morphology of its sexuals. An inspection of colonies of M. tamarae near the type locality in 2010 indicates that young queens of M. tamarae invade Temnothorax nests and kill the host queen by throttling. The simultaneous presence of two slave species in a single colony (an undescribed species related to T. nylanderi and a species morphologically resembling $T$. unifasciatus) indicates that $M$. tamarae is an active slave-maker. The genetic structure of the colonies matches that expected for a monogynous and monandrous ant, but three of eight colonies inspected appeared to contain workers belonging to an additional genetic lineage.
\end{abstract}

\section{INTRODUCTION}

Ants are indisputedly one of the big successes in evolution. Their complex cooperative life enables them to thrive in numerous ecological niches (Wilson, 1971; Hölldobler \& Wilson, 1990, 2008), but at the same time makes them particularly vulnerable to exploitation by pathogens or parasites (Schmid-Hempel, 1998). Among the latter are slave-making ants ("dulotic ants"; Wilson, 1975; Buschinger, 1986, 2009; Hölldobler \& Wilson 1990; d'Ettorre \& Heinze, 2001). Instead of founding new societies independently, young slave-maker queens usurp the nests of other ant species, in which they kill or expel the resident queen(s) and often also adult workers. Host workers that later emerge in the conquered nest misidentify the slavemaker queen as their own (e.g., Lenoir et al., 2001) and, as in unparasitized nests, take over all the daily duties in the colony. Workers produced by the slave-maker queen herself do not engage in brood care or foraging but instead pillage pupae from host nests in the neighborhood to replenish the stock of slaves "at home" (Wilson, 1971; Buschinger, 1986, 2009; Hölldobler \& Wilson, 1990; d'Ettorre \& Heinze, 2001).

Myrmoxenus Ruzsky, 1902 is the most species-rich of six or more clades of slave-making ants that have evolved in the myrmicine tribe Formicoxenini (Beibl et al., 2005). It comprises 10 to 12 species in Southern Europe and Northern Africa (Buschinger, 1989; Schulz \& Sanetra, 2002). Two workers collected in 1963 in Georgia (Jijilashvili, 1967) were described as M. tamarae (Arnol'di, 1968), but since then no additional specimens of this taxon have been collected. Here we report on the results of two field trips to the type locality of M. tamarae near Daba, Borjomi district, Georgia, during which we collected a total of nine colonies of this rare and probably endangered species of ant. We describe in detail the habitat of this ant, morphology of its sexuals and social and genetic composition of its colonies. A multidisciplinary comparison of M. tamarae and other species of Myrmoxenus does not support the view that $M$. tamarae is a junior synonym of $M$. ravouxi (André, 1896) and indicate that it can be considered as a valid species (Gratiashvili et al., 2014).

\section{MATERIAL AND METHODS}

\section{Ant collecting and culture}

Colonies of M. tamarae and its two host species were collected in August $2010(\mathrm{n}=5)$ and June $2011(\mathrm{n}=4)$ from their nests under pine bark and in rock crevices at the type locality near Daba, Borjomi Gorge (Borjomi district, South Georgia) (Fig. 1a). The structure of six colonies was investigated immediately after sampling. Then the colonies were transferred to laboratories in Tbilisi and Regensburg and kept in standard three-chambered plastic boxes with a plaster floor under semi-natural conditions as described previously for other formicoxenine ants (Buschinger, 1974; Heinze \& Ortius, 1991).

\section{Morphometry}

We measured 21 morphological characters of each of 20 mounted and dried workers (from six nests), five queens (incl. female sexuals, from two nests), and five males (from one nest) using a pin-holding stage, permitting unlimited rotation around the $\mathrm{X}, \mathrm{Y}$ and $\mathrm{Z}$ axes, and a Wild M 10 stereomicroscope equipped with a $1.6 \times$ plan-apochromatic objective at magnifications between $200 \times$ and $320 \times$. Measurements are defined by Seifert (2006) and Gratiashvili et al. (2014). Automontage pictures were produced using a Keyence VHX 500 FD digital microscope. 

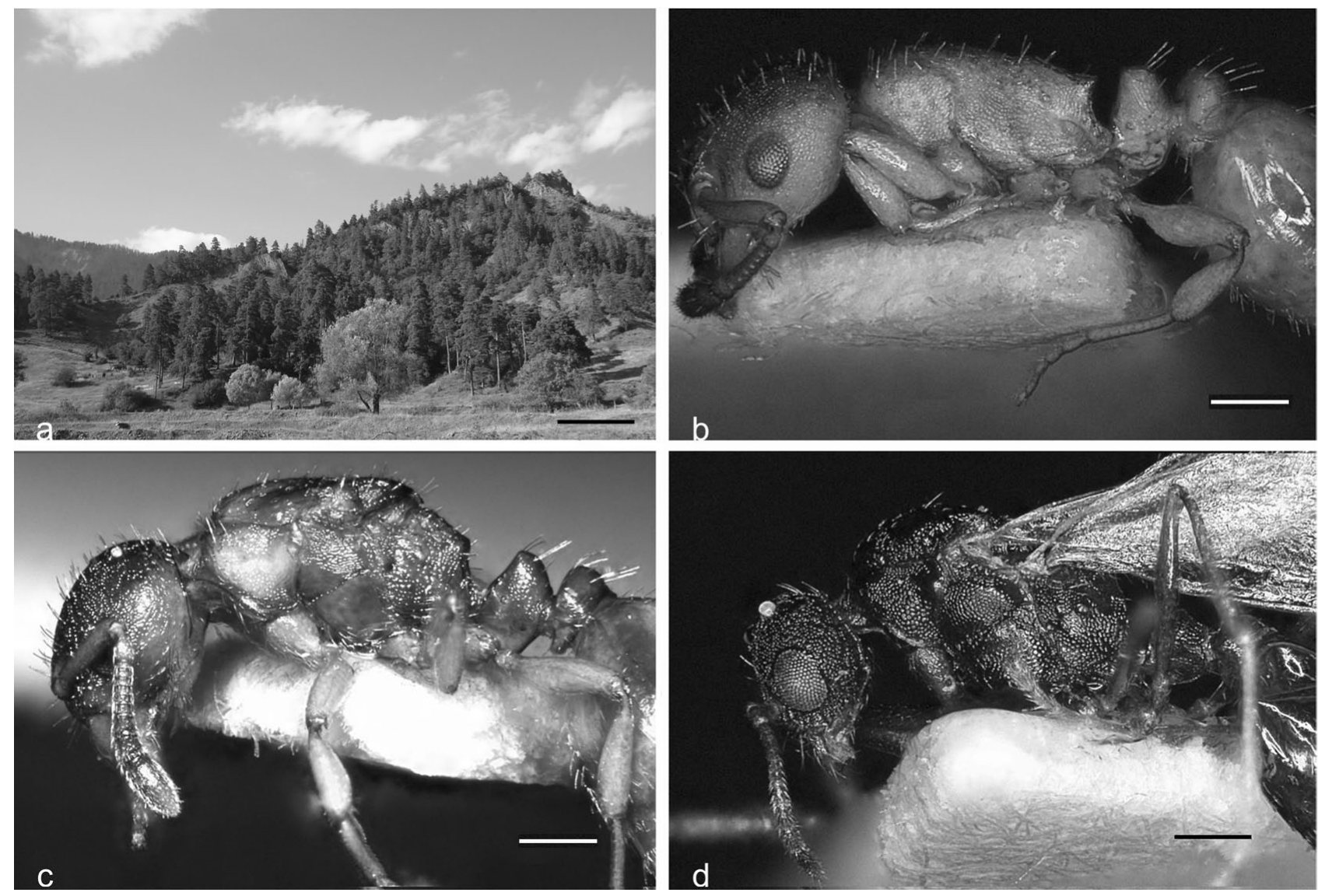

Fig. 1: Myrmoxenus tamarae (Arnol'di, 1968). a - type locality near Daba, Georgia (bar $=5 \mathrm{~m}$ ); b - worker; $\mathrm{c}-$ queen; $\mathrm{d}-\mathrm{male}$ (bars for $b-d=250 \mu \mathrm{m}$ ).

\section{Sociogenetic analysis}

Genomic DNA was extracted from 60 workers from eight colonies (3 to 10 per colony) using a CTAB-protocol (Sambrook \& Russell, 2001). PCR was performed using primers and methods previously established for Myrmoxenus ravouxi (Suefuji et al., 2011; Suefuji \& Heinze, 2014) in $20 \mu$ reaction volumes [1 $\mu 1$ DNA template, $0.1 \mu 11 \mathrm{U}$ Taq polymerase (Fermentas), $0.8 \mu 15$ $\mu \mathrm{M}$ of each forward and reverse primer (MWG Biotech; forward primer labeled with 6-FAM, TET or HEX), $2 \mu 110 \times$ Taq buffer (Fermentas), $4 \mu 11 \times$ Enhancer (PEQLAB), $1.6 \mu 125 \mathrm{mM} \mathrm{MgCl}_{2}$, $4 \mu \mathrm{l} 1 \mathrm{mM}$ of each dNTPs (Fermentas), 5.7 $\mu \mathrm{l}$ PCR water] in Eppendorf Mastercyclers with the cycling program described by Suefuji \& Heinze (2014) ( 32 cycles of $1 \mathrm{~min} 15 \mathrm{~s}$ at $94^{\circ} \mathrm{C}, 45 \mathrm{~s}$ at $50-60^{\circ} \mathrm{C}, 45 \mathrm{~s}$ at $72^{\circ} \mathrm{C}$, preceeded by $4 \mathrm{~min}$ at $94^{\circ} \mathrm{C}$ and followed by $30 \mathrm{~s}$ at $72^{\circ} \mathrm{C}$ ). After adding GeneScan-500 (Tamra) size standard, we analyzed the labelled amplification products using an ABI PRISM 310 Genetic Analyzer with a 310 Genetic Analyzer Capillary $47 \mathrm{~cm}$ and POP4-Polymer. Loci were genotyped using GeneScan 3.1 (PE Biosystems).

We determined the colony structure of $M$. tamarae by genotyping workers at loci 2MS60, 2MS65 (Suefuji et al., 2011) and 2MS86II (forward primer: AGA TTC ACT TGA AGC AGG AGC; reverse primer: ACG CTT GGG CAT AAT AAA AAA TC). Standard population genetic parameters (number of alleles, expected and observed heterozygosities, frequency of null alleles) were determined using the software Cervus 3.03 (Kalinowski et al., 2007). Worker relatedness was estimated following Queller \& Goodnight (1989) using GenAlEx (Genetic Analysis in Excel, an Excel add-in: Peakall \& Smouse, 2012). Standard errors were obtained by jackknifing over loci. Mean relatedness estimates were tested against the value expected for workers in monogynous and monandrous ant colonies $(0.75)$ using t-test.

\section{RESULTS}

The type locality of M. tamarae is on the south-eastern slope of the Gvirgvina mountains above the right bank of Gujaretistskali river (Fig. 1a) near the cemetery at Daba (Borjomi district, Southern Georgia; $41^{\circ} 48.5^{\prime} \mathrm{N}, 43^{\circ} 27^{\prime} \mathrm{E}$; 1000-1016 $\mathrm{m}$ a.s.1.). The habitat is mixed forest with Scots pine (Pinus sylvestris var. hamata) and, less abundant, Caucasian spruce (Picea orientalis) and a xerophyte herbaceous plant cover ("Pineta xeroherbosa": Akhalkatshi \& Tarkhnishvili, 2012; complete list of vegetation in Table 1). Numerous nests of two species of Temnothorax Mayr, 1861 were found under the uppermost bark layers at the base of living pines and in rock crevices. Approximately $8 \%$ of the Temnothorax colonies inspected were parasitized, i.e., contained workers and / or queens of M. tamarae.

Colonies of $M$. tamarae contained a single $M$. tamarae queen, 5 to $22 M$. tamarae workers $(\mathrm{n}=6$, median 8$)$ and 16 to 48 Temnothorax host workers ( $\mathrm{n}=6$, median 18). Two colonies collected in the field in August 2010 contained sexuals of $M$. tamarae $(3 q$ and $8 \uparrow / 1 \hat{\zeta})$ and in colonies collected in June 2011 sexuals eclosed in the laboratory in early August $(10+/ 1 \hat{\jmath} ; 2 q / 13 \hat{\jmath} ; 1 q / 4 \hat{\jmath})$. Workers, queens, and males of $M$. tamarae very closely resemble those of other Myrmoxenus species (Figs 1b-d; Table 2), in particular M. ravouxi. At present, workers of $M$. ravouxi 
TABLE 1. Complete list of the vegetation found at the type locality of the slave-making ant Myrmoxenus tamarae at Daba, Georgia.

Trees Acer laetum, Carpinus orientalis, Picea orientalis, Pinus kochiana, Quercus macranthera

Shrubs Berberis vulgaris, Chamaecytisus caucasicus, Rosa canina, Rubus fruticosus

Asperula orientalis, Astracantha microcephala, Bellis perennis, Brachypodium sylvaticum, Carex buschiorum, Centaurea bella, Cerastium sosnowskyi, Coeloglossum viride, Coluteocarpus vesicaria, Dactylorhiza euxina, Leucanthemum vulgare, Onobrychis sosnowskyi, Onosma rupestris, Orobus laxiflorus, Platanthera chlorantha, Poa nemoralis, Prunella vulgaris, Scutellaria sosnowskyi, Sempervivum sosnowskyi, Sesleria anatolica, Silene compacta, S. dianthoides, Stachys annua

TABLE 2. Means of morphometric data of samples of workers, queens and males of Myrmoxenus tamarae. Data are arithmetic means \pm standard deviations. Upper and lower extremes are given in square brackets. $n$ is the number of colonies sampled, $i$ the total number of individuals studied in these samples. Characters were measured as defined by Seifert (2006) and Gratiashvili et al. (2014).

\begin{tabular}{|c|c|c|c|c|}
\hline Abbreviation & Definition of measurements and ratios & $\begin{array}{c}\text { Workers } \\
(\mathrm{n}=6 ; \mathrm{i}=20)\end{array}$ & $\begin{array}{c}\text { Queens } \\
(\mathrm{n}=2 ; \mathrm{i}=5)\end{array}$ & $\begin{array}{c}\text { Males } \\
(\mathrm{n}=1 ; \mathrm{i}=5)\end{array}$ \\
\hline CL & maximum cephalic length in median line $[\mu \mathrm{m}]$ & $\begin{array}{c}639.034 \pm 30.042 \\
{[689.720 ; 572.628]}\end{array}$ & $\begin{array}{c}638.552 \pm 18.502 \\
{[661.650 ; 617.540]}\end{array}$ & $\begin{array}{c}511.676 \pm 11.553 \\
{[529.320 ; 501.250]}\end{array}$ \\
\hline $\mathrm{CW}$ & maximum cephalic width $[\mu \mathrm{m}]$ & $\begin{array}{c}613.851 \pm 41.900 \\
{[693.730 ; 545.360]}\end{array}$ & $\begin{array}{c}623.154 \pm 10.457 \\
{[633.580 ; 609.520]}\end{array}$ & $\begin{array}{c}580.648 \pm 22.399 \\
{[601.500 ; 553.380]}\end{array}$ \\
\hline $\mathrm{CS}$ & arithmetic mean of CL and $\mathrm{CW}[\mu \mathrm{m}]$ & $\begin{array}{c}626.442 \pm 34.573 \\
{[683.705 ; 558.994]}\end{array}$ & $\begin{array}{c}630.853 \pm 8.796 \\
{[641.600 ; 619.946]}\end{array}$ & $\begin{array}{c}546.162 \pm 15.438 \\
{[565.410 ; 529.320]}\end{array}$ \\
\hline $\mathrm{CL} / \mathrm{CW}$ & $\begin{array}{l}\text { maximum cephalic length in median line / } \\
\text { maximum cephalic width }\end{array}$ & $\begin{array}{l}1.043 \pm 0.039 \\
{[1.096 ; 0.971]}\end{array}$ & $\begin{array}{l}1.029 \pm 0.044 \\
{[1.066 ; 0.975]}\end{array}$ & $\begin{array}{l}0.882 \pm 0.027 \\
{[0.913 ; 0.840]}\end{array}$ \\
\hline SL / CS & maximum straight line scape length / CS & $\begin{array}{c}0.729 \pm 0.042 \\
{[0.844 ; 0.665]}\end{array}$ & $\begin{array}{l}0.692 \pm 0.041 \\
{[0.739 ; 0.643]}\end{array}$ & $\begin{array}{l}0.311 \pm 0.019 \\
{[0.327 ; 0.289]}\end{array}$ \\
\hline $\mathrm{PoOc} / \mathrm{CS}$ & postocular distance / CS & $\begin{array}{l}0.395 \pm 0.018 \\
{[0.423 ; 0.369]}\end{array}$ & $\begin{array}{l}0.373 \pm 0.010 \\
{[0.388 ; 0.359]}\end{array}$ & $\begin{array}{l}0.374 \pm 0.008 \\
{[0.381 ; 0.362]}\end{array}$ \\
\hline FRS / CS & distance of frontal carinae / CS & $\begin{array}{l}0.346 \pm 0.049 \\
{[0.537 ; 0.299]}\end{array}$ & $\begin{array}{l}0.342 \pm 0.016 \\
{[0.369 ; 0.329]}\end{array}$ & $\mathrm{n} / \mathrm{a}$ \\
\hline $\mathrm{EYE} / \mathrm{CS}$ & $\begin{array}{c}\text { arithmetic mean of large and small diameter of } \\
\text { the elliptical compound eye / CS }\end{array}$ & $\begin{array}{l}0.246 \pm 0.011 \\
{[0.265 ; 0.223]}\end{array}$ & $\begin{array}{l}0.285 \pm 0.010 \\
{[0.297 ; 0.270]}\end{array}$ & $\begin{array}{l}0.377 \pm 0.018 \\
{[0.394 ; 0.358]}\end{array}$ \\
\hline MW & maximum mesosoma width $[\mu \mathrm{m}]$ & $\begin{array}{c}404.774 \pm 29.563 \\
{[453.010 ; 333.395]}\end{array}$ & $\begin{array}{c}524.779 \pm 13,027 \\
{[547.175 ; 514,090]}\end{array}$ & $\begin{array}{c}536.486 \pm 26.103 \\
{[580.260 ; 514.090]}\end{array}$ \\
\hline $\mathrm{MW} / \mathrm{CS}$ & maximum mesosoma width/ CS & $\begin{array}{l}0.646 \pm 0.033 \\
{[0.713 ; 0.546]}\end{array}$ & $\begin{array}{l}0.832 \pm 0.014 \\
{[0.852 ; 0.814]}\end{array}$ & $\begin{array}{l}0.982 \pm 0.042 \\
{[1.026 ; 0.932]}\end{array}$ \\
\hline $\mathrm{SPBA} / \mathrm{CS}$ & $\begin{array}{l}\text { smallest distance between lateral margins of } \\
\text { propodeal spines / CS }\end{array}$ & $\begin{array}{l}0.286 \pm 0.015 \\
{[0.319 ; 0.261]}\end{array}$ & $\begin{array}{l}0.388 \pm 0.028 \\
{[0.420 ; 0.353]}\end{array}$ & $\mathrm{n} / \mathrm{a}$ \\
\hline $\mathrm{SPTI} / \mathrm{CS}$ & distance of spine tips in dorsal view / CS & $\begin{array}{l}0.328 \pm 0.019 \\
{[0.363 ; 0.300]}\end{array}$ & $\begin{array}{l}0.357 \pm 0.029 \\
{[0.397 ; 0.325]}\end{array}$ & $\mathrm{n} / \mathrm{a}$ \\
\hline SPST / CS & $\begin{array}{l}\text { distance between center of propodeal stigma and } \\
\text { tip of spine / CS }\end{array}$ & $\begin{array}{l}0.259 \pm 0.012 \\
{[0.283 ; 0.238]}\end{array}$ & $\begin{array}{l}0.251 \pm 0.025 \\
{[0.279 ; 0.210]}\end{array}$ & $\begin{array}{l}0.380 \pm 0.058 \\
{[0.413 ; 0.277]}\end{array}$ \\
\hline $\mathrm{PEW} / \mathrm{CS}$ & maximum petiole width / CS & $\begin{array}{l}0.292 \pm 0.024 \\
{[0.374 ; 0.253]}\end{array}$ & $\begin{array}{l}0.286 \pm 0.008 \\
{[0.300 ; 0.279]}\end{array}$ & $\begin{array}{l}0.305 \pm 0.023 \\
{[0.332 ; 0.276]}\end{array}$ \\
\hline $\mathrm{PPW} / \mathrm{CS}$ & maximum post petiole width / CS & $\begin{array}{l}0.411 \pm 0.020 \\
{[0.452 ; 0.378]}\end{array}$ & $\begin{array}{l}0.416 \pm 0.010 \\
{[0.428 ; 0.407]}\end{array}$ & $\begin{array}{l}0.434 \pm 0.023 \\
{[0.471 ; 0.414]}\end{array}$ \\
\hline $\mathrm{PEH} / \mathrm{CS}$ & maximum petiole height / CS & $\begin{array}{l}0.587 \pm 0.031 \\
{[0.637 ; 0.515]}\end{array}$ & $\begin{array}{l}0.595 \pm 0.026 \\
{[0.639 ; 0.575]}\end{array}$ & $\begin{array}{l}0.433 \pm 0.022 \\
{[0.471 ; 0.413]}\end{array}$ \\
\hline $\mathrm{SPH} / \mathrm{CS}$ & $\begin{array}{l}\text { distance between center of petiolar stigma and } \\
\text { apex of petiolar sternal process / CS }\end{array}$ & $\begin{array}{l}0.276 \pm 0.023 \\
{[0.311 ; 0.225]}\end{array}$ & $\begin{array}{l}0.286 \pm 0.027 \\
{[0.311 ; 0.254]}\end{array}$ & $\begin{array}{l}0.267 \pm 0.016 \\
{[0.288 ; 0.250]}\end{array}$ \\
\hline ML & mesosoma length $[\mu \mathrm{m}]$ & $\begin{array}{c}795.383 \pm 45.242 \\
{[890.220 ; 689.720]}\end{array}$ & $\begin{array}{c}942.812 \pm 51.630 \\
{[1000.890 ; 862.150]}\end{array}$ & $\begin{array}{c}1006.956 \pm 38.231 \\
{[1041.330 ; 960.450]}\end{array}$ \\
\hline $\mathrm{ML} / \mathrm{CS}$ & mesosoma length / CS & $\begin{array}{l}1.270 \pm 0.038 \\
{[1.317 ; 1.208]}\end{array}$ & $\begin{array}{l}1.495 \pm 0.068 \\
{[1.570 ; 1.391]}\end{array}$ & $\begin{array}{l}1.843 \pm 0.025 \\
{[1.870 ; 1.808]}\end{array}$ \\
\hline $\mathrm{MH} / \mathrm{CS}$ & maximum mesosoma height / CS & $\begin{array}{l}0.569 \pm 0.031 \\
{[0.640 ; 0.532]}\end{array}$ & $\begin{array}{l}0.920 \pm 0.101 \\
{[1.059 ; 0.813]}\end{array}$ & $\begin{array}{l}1.167 \pm 0.030 \\
{[1.209 ; 1.134]}\end{array}$ \\
\hline NOL / CS & $\begin{array}{l}\text { distance between anteriormost and posteriormost } \\
\text { point of petiole measured along a horizontal line } \\
\text { crossing center of stigma / CS }\end{array}$ & $\begin{array}{l}0.364 \pm 0.020 \\
{[0.400 ; 0.325]}\end{array}$ & $\begin{array}{l}0.363 \pm 0.037 \\
{[0.399 ; 0.317]}\end{array}$ & $\begin{array}{c}0.414 \pm 0.019 \\
{[0.441 ; 0.391]}\end{array}$ \\
\hline PHL / CS & length of longest hair on petiole / CS & $\begin{array}{c}0.177 \pm 0.022 \\
{[0.216 ; 0.118]}\end{array}$ & $\begin{array}{c}0.205 \pm 0.013 \\
{[0.226 ; 0.194]}\end{array}$ & $\begin{array}{c}0.179 \pm 0.032 \\
{[0.216 ; 0.129]}\end{array}$ \\
\hline PnHL / CS & length of longest hair on pronotum / CS & $\begin{array}{l}0.129 \pm 0.024 \\
{[0.170 ; 0.091]}\end{array}$ & $\begin{array}{l}0.147 \pm 0.038 \\
{[0.191 ; 0.106]}\end{array}$ & $\begin{array}{l}0.160 \pm 0.015 \\
{[0.175 ; 0.135]}\end{array}$ \\
\hline
\end{tabular}


TABLE 3. Primer sequences, repeat motives and annealing temperature $\left(\mathrm{T}_{\mathrm{a}}\right)$ of the three microsatellite loci studied in the slave-making ant Myrmoxenus tamarae. Allele size range, number of alleles $(A)$, expected and observed heterozygosities $\left(\mathrm{H}_{\text {exp }}, \mathrm{H}_{\text {obs }}\right)$ were calculated. $N$ indicates the number of individuals that were genotyped (ten per colony).

\begin{tabular}{lccccccc}
\hline Locus & GB accession & $\mathrm{T}_{\mathrm{a}}\left({ }^{\circ} \mathrm{C}\right)$ & Size range (bp) & $N$ & $A$ & $\mathrm{H}_{\text {exp }}$ & $\mathrm{H}_{\text {obs }}$ \\
\hline 2MS60 & HQ154543 & 60 & $115-137$ & 60 & 6 & 0.682 & 0.633 \\
2MS65 & HQ154544 & 60 & $139-155$ & 60 & 7 & 0.789 & 0.650 \\
2MS86II & not available & 60 & $145-151$ & 60 & 4 & 0.686 & 0.883 \\
\hline
\end{tabular}

and $M$. tamarae can be distinguished only by complex statistical methods (Gratiashvili et al., 2014).

Field data show that at the type locality M. tamarae utilizes as hosts two species of Temnothorax. Six nests contained host workers of a species morphologically identified as T. unifasciatus (Latreille, 1798) by B. Seifert and A. Schulz, but genetically forming the out group to Central European T. unifasciatus and T. nigriceps (Mayr, 1855) (based on a sequence of the mitochondrial gene COI / COII, M. Suefuji, unpubl.). Two nests contained workers of " $T$. crasecundus" (provisional name of a recognized morphospecies currently being described by B. Seifert and S. Csősz), which is a species closely related to $T$. nylanderi (Foerster, 1850) and T. crassispinus (Karavaiev, 1926). One colony contained both slave species. In one laboratory colony we observed a young $M$. tamarae queen killing a "T. crasecundus" host queen by throttling.

The three microsatellite loci studied were sufficiently variable to give a crude estimate of genetic colony structure. Locus 2MS60 had six alleles, 2MS65 seven alleles and 2MS86II four alleles (mean number of alleles: 5.67; Table 3). The frequency of potential null alleles was estimated to be lower than 0.2 at each locus. Mean relatedness, estimated following Queller \& Goodnight (1989), was $0.627 \pm$ SE 0.086 , which is not significantly different from the value of 0.75 expected for monogyny and monandry (a single, singly mated queen per colony; $\mathrm{t}=1.489, \mathrm{p}$ $=0.180)$. Nevertheless, in three of eight colonies we found two or three individuals with a genotype at one locus that was not compatible with monogyny and monandry.

\section{DISCUSSION}

M. tamarae closely resembles other slave-making species of the genus Myrmoxenus, in particular M. ravouxi, in morphology and life history. Workers, and presumably also queens and males, of $M$. tamarae can be separated from those of $M$. ravouxi only by an exploratory statistical analysis of multiple morphological characters, as in other pairs of closely related or cryptic species (e.g., Seifert, 2013; Seifert et al., 2013; Csősz et al., 2013). M. tamarae has therefore been considered to be synonymous with M. ravouxi (Buschinger, 1989; Schulz \& Sanetra, 2002), but our recent integrative study revealed subtle differences between the two taxa, which do not support the proposed synonymy (Gratiashvili et al., 2014).

The few colonies of $M$. tamarae collected provide useful information about the life history of this species, which support our view that $M$. tamarae is a close relative of $M$. ravouxi (Gratiashvili et al., 2014). One colony contained workers from two host species, which demonstrates that $M$. tamarae is an active slave-maker like $M$. ravouxi. At Daba, M. tamarae utilizes a species of Temnothorax, which morphologically resembles $T$. unifasciatus. The other host is $T$. "crasecundus", a species closely related to T. nylanderi and T. crassispinus. This is particularly surprising, as species of this taxonomic group, though abundant throughout much of the range of Myrmoxenus, are rarely if ever parasitized (Buschinger, 1989; Delattre et al., 2012, 2013; but see Mei, 1992). Active slave-raiding may also be the explanation for genotypes of $M$. tamarae workers that did not match the typical sociogenetic structure of Myrmoxenus, monogyny and monandry (a single, singly mated queen per colony). Similarly aberrant genotypes are recorded in a large fraction of $M$. ravouxi colonies in Southern Germany. Genotyping the offspring produced by queens under controlled laboratory conditions strongly supported monogyny and monandry and suggested that genetic heterogeneity in the field might result from colony fusion or raiding of neighboring colonies or adoption of stray Myrmoxenus workers (Suefuji \& Heinze, 2014).

As is the case for all species of Myrmoxenus, queens of $M$. tamarae appear to eliminate the host queen by throttling. We observed such an interaction in a colony that had been queenless when collected one year before. Presumably sexuals of both the host and parasite eclosed from brood in the laboratory. Unfortunately we could not determine whether the queens were inseminated. While sexuals of $M$. ravouxi leave the nest to mate during nuptial flights, those of M. kraussei (Emery, 1915) and other species regularly mate in the nest, which results in considerable heterozygote deficiency (Suefuji \& Heinze, 2014). The genetic data, albeit based on a small sample and only three loci, do not support regular inbreeding in $M$. tamarae. It is therefore unlikely that the $M$. tamarae queen had been inseminated.

Genetic diversity in the population studied was relatively high and matched that found at other loci in a similarly small number of colonies of $M$. ravouxi (Suefuji \& Heinze, 2014, population Schönhofen; average number of alleles 6.2). This indicates that the population at the type locality does not suffer from inbreeding and might probably be larger than concluded from the difficulties of finding slavemaker colonies.

The type locality at Daba is the only known population of M. tamarae in Georgia, but the finding of morphologically and genetically similar ants in Northern Turkey close to the Georgian border suggests that the species might be more common throughout the Lesser Caucasus and other 
mountainous areas. At least the habitat, dry and open mixed forests with pines, firs and oaks, and the two host species are abundant in many places in this area.

ACKNOWLEDGEMENTS. We are grateful to B. Seifert (Senckenberg Museum für Naturkunde Görlitz) for identification of Temnothorax and Z. Asanidze (Ilia State University, Tbilisi, Georgia) for assessing habitat type and identification of plants from the type locality. This research was funded by DFG (HE 1623/30-1), DAAD (ref. A/10/77630) and a grant from Shota Rustaveli National Science Foundation (04/24).

\section{REFERENCES}

AKhalkatsi M. \& TARKhnishvili D. 2012: Habitats of Georgia. PGSSRP Commission paper, Tbilisi, 118 pp.

Beibl J., Stuart R.J., Heinze J. \& FoitziK S. 2005: Six origins of slavery in formicoxenine ants. — Insectes Soc. 52: 291-297.

Buschinger A. 1974: Mono- und Polygynie in Insektensozietäten. In Schmidt G.H. (ed.): Sozialpolymorphismus bei Insekten. Wissenschaftliche Verlagsgesellschaft, Stuttgart, pp. 862-896.

BUSCHINGER A. 1986: Evolution of social parasitism in ants. Trends Ecol. Evol. 1: 155-160.

Buschinger A. 1989: Evolution, speciation, and inbreeding in the parasitic ant genus Epimyrma (Hymenoptera, Formicidae). J. Evol. Biol. 2: 265-283.

Buschinger A. 2009: Social parasitism in ants: a review (Hymenoptera: Formicidae). - Myrmecol. News 12: 219-235.

Csősz S., Seifert B., Müller B., Trindl A., Schulz A. \& Heinze J. 2014: Cryptic diversity in the Mediterranean Temnothorax lichtensteini species complex (Hymenoptera: Formicidae). Org. Divers. Evol. 14: 75-88.

Delattre O., Blatrix R., Châline N., Chameron S., Fédou A., Leroy C. \& JAISSON P. 2012: Do host species evolve a specific response to slave-making ants? - Front. Zool. 9: 38.

Delattre O., Châline N., Chameron S., Lecoutey E. \& Jaisson P. 2013: Opportunist slave-making ants Myrmoxenus ravouxi discriminate different host species from a non-host species. Insectes Soc. 60: 7-13.

D'Ettorre P. \& Heinze J. 2001: Sociobiology of slave-making ants. - Acta Ethol. 3: 67-82.

Gratiashvili N., Bernadou A., Suefuji M., Seifert B. \& Heinze J. 2014: The Caucaso-Anatolian slave-making ant Myrmoxenus tamarae (Arnoldi, 1968) and its more widely distributed congener Myrmoxenus ravouxi (André, 1896): a multidisciplinary comparison (Hymenoptera: Formicidae). - Org. Divers. Evol. 14: 259-267.

Heinze J. \& Ortius D. 1991: Social organization of Leptothorax acervorum from Alaska (Hymenoptera: Formicidae). Psyche 98: 227-240.

Hölldobler B. \& Wilson E.O. 1990: The ants. The Belknap Press of Harvard University Press, Cambridge, MA, 732 pp.

Hölldobler B. \& Wilson E.O. 2008: The Superorganism: The Beauty, Elegance, and Strangeness of Insect Societies. W.W. Norton \& Company, New York, 521 pp.
JiJlLASHVILI T. 1967: Material on the ant fauna of the BorjomiBakuriani forests. In Japaridze N. \& Kokhia S. (eds): Materials on the Fauna of Georgia, Part II. Metsniereba, Tbilisi, pp. 50-70 [in Russian].

Kalinowski S.T., Taner M.L. \& Marshall T.C. 2007: Revising how the computer program CERVUS accommodates genotyping error increases success in paternity assignment. - Mol. Ecol. 16: 1099-1106.

Lenoir A., D'Ettorre P., Errard C. \& Hefetz A. 2001: Chemical ecology and social parasitism in ants. - Annu. Rev. Entomol. 46: 573-599.

Mer M. 1992: A survey of the socially parasitic ant genera Epimyrma Emery, 1915 and Chalepoxenus Menozzi, 1922 in Italy (Hymenoptera, Formicidae, Myrmicinae). — Insectes Soc. 39: 145-156.

Peakall R. \& Smouse P.E. 2012: GenAlEx 6.5: genetic analysis in Excel. Population genetic software for teaching and research - an update. - Bioinformatics 28: 2537-2539.

Queller D.C. \& Goodnight K.F. 1989: Estimating relatedness using genetic markers. - Evolution 43: 258-275.

SAmbrook J. \& Russell D. 2001: Molecular Cloning. 3rd Ed. Cold Spring Harbor Laboratory Press, New York, 2344 pp.

Schmid-Hempel P. 1998: Parasites in Social Insects. Princeton University Press, Princeton, NJ, 409 pp.

Schulz A. \& Sanetra M. 2002: Notes on the socially parasitic ants of Turkey and the synonymy of Epimyrma (Hymenoptera: Formicidae). - Entomofauna 23: 157-172.

Seifert B. 2006: Temnothorax saxonicus (Seifert, 1995) stat. nov., comb. nov. - a parapatric, closely-related species of $T$. sordidulus (Müller, 1923) comb. nov., stat nov. and description of two new closely-related species, $T$. schoedli sp. n. and $T$. artvinense sp. n. from Turkey (Hymenoptera: Formicidae). Myrmecol. News 8: 1-12.

SeIFERT B. 2013: Hypoponera ergatandria (Forel, 1893) - a cosmopolitan tramp species different from $H$. punctatissima (Roger, 1859) (Hymenoptera: Formicidae). — Soil Org. 85: 189-201.

SeIfert B., Ritz M. \& Csősz S. 2013: Application of exploratory data analyses opens a new perspective in morphology-based alpha-taxonomy of eusocial organisms. - Myrmecol. News 19: $1-15$.

SuefujI M. \& HeInze J. 2014: The genetic population structure of two socially parasitic ants: the active slave-maker Myrmoxenus ravouxi and the "degenerate slave-maker" M. kraussei. - Conserv. Genet. 15: 201-211.

Suefuj M., Trindl A. \& Heinze J. 2011: Characterization of 13 microsatellite markers for the threatened, slave-making ant Myrmoxenus ravouxi (Formicidae: Myrmicinae). - Conserv. Genet. Resour. 3: 229-231.

WiLson E.O. 1971: The Insect Societies. Belknap Press of Harvard University Press, Cambridge, 548 pp.

Received June 4, 2014; revised and accepted October 9, 2014 Prepublished online December 5, 2014 